\title{
Seed Priming with Boron Improves Achene Yield and Oil Contents of Sunflower
}

\author{
Muhammad Kashif Asghar", Muhammad Aqeel Sarwar, ${ }^{1,2}$, Shahid Riaz Malik ${ }^{2}$, Waqas Ahmad ${ }^{3}$, Sumaira \\ Zareen ${ }^{4}$, Safdar Ali ${ }^{5}$ and Abid Ali ${ }^{6}$
}

${ }^{1}$ Department of Agronomy, University of Agriculture, Faisalabad, Pakistan; ${ }^{2}$ Crop Sciences Institute, National Agricultural Research Centre, Islamabad, Pakistan; ${ }^{3}$ College of Agriculture, Bahauddin Zakariya University, Bahadur Sub-campus, Layyah, Pakistan; ${ }^{4}$ Department of Biotechnology, International Islamic University Islamabad, Pakistan; ${ }^{5}$ Department of Agronomy, Pir Mehr Ali Shah, Arid Agriculture University, Rawalpindi, Pakistan; ${ }^{6}$ Cotton Research Institute khanpur, Pakistan.

Abstract | Boron deficiency is second most dominant micronutrient problem around the world and it is an
important micronutrient required for plant growth and development. So a field study was conducted to ex-
plore the potential of boron seed priming on yield and quality of sunflower hybrids at Agronomic Research
Farm, University of Agriculture, Faisalabad. The achenes of two different sunflower hybrids i.e. Hysun-33
and FH-331 were subjected to different priming treatments including hydropriming, osmopriming (with 1,
0.1 and $0.01 \mathrm{mM} \mathrm{B)} \mathrm{using} \mathrm{boric} \mathrm{acid} \mathrm{as} \mathrm{a} \mathrm{source} \mathrm{of} \mathrm{B.} \mathrm{The} \mathrm{experiment} \mathrm{was} \mathrm{laid} \mathrm{out} \mathrm{in} \mathrm{randomized} \mathrm{complete}$
block design with factorial arrangement in triplicate run. Results from the experiment revealed that all the
seed treatments significantly improved achene yield, yield attributes and oil contents of sunflower. However,
seed priming with $1 \mathrm{mM} \mathrm{B} \mathrm{solution} \mathrm{was} \mathrm{the} \mathrm{best} \mathrm{treatment} \mathrm{in} \mathrm{improving} \mathrm{achene} \mathrm{yield} \mathrm{and} \mathrm{oil} \mathrm{contents} \mathrm{of}$
sunflower hybrid. While in case of hybrids HYSUN-33 performed significantly better than FH-331 for all
studied parameters except for oil contents. However, the interaction between sunflower hybrids and seed
priming treatments was non-significant for most of the traits.
Received | January 26, 2018; Accepted | November 1,2018; Published | December 13, 2018
*Correspondence | Muhammad Aqeel Sarwar, Department of Agronomy, University of Agriculture, Faisalabad, Pakistan; Email: maqeeluaf@
gmail.com
Citation | Asghar, M.K., M.A. Sarwar, S.R. Malik, W. Ahmad, S. Zareen, S. Ali and A. Ali. 2019. Seed priming with boron improves achene
yield and oil contents of sunflower. Pakistan Journal of Agricultural Research, 32(1): 73-77.
DOI | http://dx.doi.org/10.17582/journal.pjar/2019/32.1.73.77
Keywords | Boron, Seed priming, Sunflower, Achene yield

\section{Introduction}

$\mathrm{P}$ akistan is facing a severe deficiency of edible oil and spending a huge amount 'of foreign exchange to meet the requirements through imports. This import bill is imposing a severe drain on foreign exchange reserves. Thus, the indigenous edible oil production should be enhanced to reduce drain on the national economy (GoP, 2014). Sunflower (Helianthus annuus L.) is an important non-traditional oilseed crop and is a second most source of edible oil production in the country after cottonseed (Sarwar, 2015). It is a short duration crop of 90-110 days and can be successfully grown twice in a year during spring and autumn season without disturbing the major crops like wheat, rice and cotton. Sunflower seed contains $40-47 \%$ oil and $20-27 \%$ protein contents (Saleem et al., 2003).

For ideal growth and development, 17 essential elements should be made available to crop plants. If even a single element is deficient in the soil or not well balanced with other nutrients, suppression in growth or even complete inhibition may occur. Micronutrients play an important role in the basic physiological 
processes i.e. respiration and photosynthesis (Mengel et al., 2001). However, each micronutrient has a slight range of deficiency and toxicity that should be kept under consideration during the application (Imtiazet al., 2010). Boron is an important mineral element for plant nutrition which is involved in many metabolic processes such as cell wall synthesis, phenol metabolism, membrane integrity and function, and metabolism of nucleic acid, carbohydrate, protein and indole acetic acid (Tanaka and Fujiwara, 2008). Sexual reproduction in plants is more sensitive to Boron deficiency as compared to vegetative growth (Ahmad et al., 2009). Boron deficiency is second most dominant micronutrient problem around the world (Alloway, 2008). Boron deficiency is reported in cotton growing areas of Pakistan (Abid et al., 2007). Calcareous soils of wheat and rice growing areas of Pakistan are also found to be deficient in available B (Rashid and Ryan, 2004). Therefore, correction of B deficiency through external sources is an important aspect for better yield (Alam et al., 2017).

Boron fertilizer may be delivered through fertigation, foliar spray, seed treatment and soil dressing. Although, each application method has its own merits and de-merits but application through seed treatment is gaining popularity in recent years (Rehman et al., 2012). In seed priming, seeds are soaked in solutions having low water potential for a definite period of time. Seeds are then re-dried to their original weight to facilitate routine handling (Farooq et al., 2006). Improved germination followed by good stand establishment and grain yield are attributed to develop germination-stimulating metabolites (Farooq et al.,2006). Previously, B has not been tried as priming agent in sunflower. Therefore, this study was conducted to explore the potential of seed priming with $B$ in improving achene yield and oil contents of sunflower hybrids.

\section{Materials and Methods}

\section{Seed materials}

Achenes of sunflower hybrids Hysun-33 and FH331, used in this study, were obtained from Oilseed Research Institute, Faisalabad.

\section{Seed priming treatments}

Achenes of both sunflower hybrids were soaked in solutions of boric acid [1, 0.1 and $0.01 \mathrm{~mm}(\mathrm{w} / \mathrm{v}) \mathrm{B}$ ]. Achenes soaked in aerated water and untreated seeds were taken as control. In both cases, soaking was done for $8 \mathrm{~h}$ in aerated solution (nutripriming) or water (hydropriming) keeping seed to solution ratio 1:5 (w/v). Aeration was provided by aquarium pump. After removing from the respective solution, achenes were thoroughly rinsed with water and dried in forced air under shade till original weight.

\section{Experimental details}

Four cultivations followed by two plankings were given to achieve the desirable soil structure. Treated and untreated seeds were sown on the $14^{\text {th }}$ of February 2014 with the help of dibbler at a seed rate of $6.25 \mathrm{~kg}$ $\mathrm{ha}^{-1}$ in the pattern of row-to-row distance of $75 \mathrm{~cm}$ and plant-to-plant distance of $25 \mathrm{~cm}$. The experiment was conducted in randomized complete block design (RCBD) with factorial arrangement having a net plot size of $5 \mathrm{~m} \times 3 \mathrm{~m}$ in three blocks. Nitrogen and phosphorus were applied @ 100 and $75 \mathrm{~kg} \mathrm{ha}^{-1}$, respectively in the form of Urea and DAP. Half of the nitrogen and whole of the phosphorus were applied at sowing time and remaining nitrogen was applied with first irrigation. One hoeing was done to keep the crop weed free. Observations like plant population at harvest, head diameter, number of achenes per head, 1000-achene weight, achene yield, biological yield, harvest index, achene oil contents and achene protein contents were recorded following the standard procedures.

\section{Statistical analyses}

Experimental data were analyzed statistically using statistical software MSTAT-C. Analysis of variance was used to test the significance of variance sources, while the difference among treatment means were compared using LSD test ( $\mathrm{p}=0.05)$ (Steel et al., 1997).

\section{Results and Discussion}

The study revealed that seed priming with B significantly affected head diameter, number of achenes per head, 1000-achene weight, achene yield, biological yield and harvest index of both tested sunflower hybrids (Table 1). Head diameter contributes to achene yield of sunflower because it influences both the number of achenes per head and achene size. Statistically maximum head diameter was observed in achenes exposed to seed priming with $1 \mathrm{mM} \mathrm{B}$ which was closely followed by that of with $0.1 \mathrm{mM}$ B. Instead of, minimum head diameter was observed in achenes taken as control and were not exposed to any seed treatment. Hysun-33 produced statistically bigger heads as compared to FH-331 (Table 1). 
Table 1: Effect of boron seed priming on yield and quality parameters of sunflower hybrids.

\begin{tabular}{|c|c|c|c|c|c|c|c|c|c|}
\hline Treatments & $\mathbf{P P}$ & HD & APH & TAW & AY & BY & HI & AOC & APC \\
\hline \multicolumn{10}{|l|}{ Sunflower hybrids } \\
\hline $\mathrm{H}_{1}=\mathrm{HYSUN}-33$ & 79.67 & $16.59 \mathrm{~b}$ & $936.21 \mathrm{a}$ & $53.84 \mathrm{a}$ & $2.68 \mathrm{a}$ & $10.79 \mathrm{a}$ & $24.80 \mathrm{a}$ & $39.72 \mathrm{~b}$ & $18.55 \mathrm{a}$ \\
\hline $\mathrm{H}_{2}=\mathrm{FH}-331$ & 79.40 & $15.50 \mathrm{~b}$ & $831.01 \mathrm{~b}$ & $52.66 \mathrm{~b}$ & $2.32 \mathrm{~b}$ & $10.24 \mathrm{~b}$ & $22.61 \mathrm{~b}$ & $41.49 \mathrm{a}$ & $17.85 \mathrm{~b}$ \\
\hline LSD & Ns & 0.046 & 2.471 & 0.014 & 0.016 & 0.083 & 0.202 & 0.202 & 0.095 \\
\hline \multicolumn{10}{|l|}{ B seed priming } \\
\hline $\mathrm{P}_{1}=$ Control & 79.17 & $15.58 \mathrm{~d}$ & $834.71 \mathrm{e}$ & $53.2 \mathrm{c}$ & $2.35 \mathrm{e}$ & $10.3 \mathrm{c}$ & $22.7 \mathrm{~d}$ & $40.33 c$ & $18.44 \mathrm{~b}$ \\
\hline $\mathrm{P}_{2}=$ Hydropriming & 79.50 & $16.02 \mathrm{c}$ & $878.30 \mathrm{~d}$ & $53.2 \mathrm{a}$ & $2.48 \mathrm{~d}$ & $10.5 \mathrm{~b}$ & $23.6 \mathrm{c}$ & $40.37 \mathrm{c}$ & $18.71 \mathrm{a}$ \\
\hline $\mathrm{P}_{3}=$ Osmopriming $(1 \mathrm{mM} \mathrm{B})$ & 79.83 & $16.47 \mathrm{a}$ & $921.33 \mathrm{a}$ & $53.2 \mathrm{bc}$ & $2.61 \mathrm{a}$ & $10.7 \mathrm{a}$ & $24.4 \mathrm{a}$ & $40.99 \mathrm{a}$ & $17.62 \mathrm{c}$ \\
\hline $\mathrm{P}_{4}=$ Osmopriming $(0.1 \mathrm{mM} \mathrm{B})$ & 79.67 & $16.13 \mathrm{~b}$ & $896.32 \mathrm{~b}$ & $53.2 \mathrm{bc}$ & $2.54 \mathrm{~b}$ & $10.6 \mathrm{ab}$ & $23.9 \mathrm{~b}$ & $40.76 \mathrm{ab}$ & $17.68 \mathrm{c}$ \\
\hline $\mathrm{P}_{5}=$ Osmopriming $(0.01 \mathrm{mM} \mathrm{B})$ & 79.50 & $16.02 \mathrm{c}$ & $887.31 \mathrm{c}$ & $53.2 \mathrm{ab}$ & $2.51 \mathrm{c}$ & $10.5 \mathrm{~b}$ & $23.8 \mathrm{bc}$ & $40.56 \mathrm{bc}$ & $18.57 \mathrm{ab}$ \\
\hline LSD & ns & 0.073 & 3.907 & 0.022 & 0.025 & 0.132 & 0.319 & 0.319 & 0.147 \\
\hline \multicolumn{10}{|c|}{ Interaction (Sunflower hybrids $\times$ B seed priming) } \\
\hline $\mathrm{H}_{1} \times \mathrm{P}_{1}$ & 79.33 & 16.10 & $879.67 \mathrm{e}$ & 53.81 & 2.50 & 10.57 & 23.69 & 39.60 & 18.79 \\
\hline $\mathrm{H}_{1} \times \mathrm{P}_{2}$ & 79.67 & 16.53 & $932.67 \mathrm{~d}$ & 53.86 & 2.67 & 10.78 & 24.76 & 39.48 & 19.09 \\
\hline $\mathrm{H}_{1} \times \mathrm{P}_{3}$ & 80.00 & 17.03 & $975.33 \mathrm{a}$ & 53.83 & 2.80 & 10.98 & 25.51 & 39.99 & 17.91 \\
\hline $\mathrm{H}_{1} \times \mathrm{P}_{4}$ & 79.67 & 16.67 & $951.33 \mathrm{~b}$ & 53.84 & 2.72 & 10.83 & 25.11 & 39.77 & 17.96 \\
\hline $\mathrm{H}_{1} \times \mathrm{P}_{5}$ & 79.67 & 16.60 & $942.00 \mathrm{c}$ & 53.85 & 2.69 & 10.81 & 24.92 & 39.74 & 19.02 \\
\hline $\mathrm{H}_{2} \times \mathrm{P}_{1}$ & 79.00 & 15.07 & $789.67 \mathrm{j}$ & 52.64 & 2.19 & 10.07 & 21.75 & 41.05 & 18.09 \\
\hline $\mathrm{H}_{2} \times \mathrm{P}_{2}$ & 79.33 & 15.50 & 824.00 i & 52.70 & 2.29 & 10.24 & 22.44 & 41.27 & 18.33 \\
\hline $\mathrm{H}_{2} \times \mathrm{P}_{3}$ & 79.67 & 15.90 & $867.33 \mathrm{f}$ & 52.65 & 2.43 & 10.38 & 23.36 & 41.98 & 17.32 \\
\hline $\mathrm{H}_{2} \times \mathrm{P}_{4}$ & 79.67 & 15.60 & $841.33 \mathrm{~g}$ & 52.65 & 2.35 & 10.29 & 22.86 & 41.75 & 17.39 \\
\hline $\mathrm{H}_{2} \times \mathrm{P}_{5}$ & 79.33 & 15.43 & $832.67 \mathrm{~h}$ & 52.67 & 2.32 & 10.24 & 22.65 & 41.38 & 18.12 \\
\hline LSD & $\mathrm{ns}$ & $\mathrm{ns}$ & 5.525 & $\mathrm{~ns}$ & ns & $\mathrm{ns}$ & $\mathrm{ns}$ & ns & $\mathrm{ns}$ \\
\hline
\end{tabular}

Ns: Non-significant; PP: Plant population at harvest per plot; HD: Head diameter (cm); APH: Achenes per head; TAW: 1000-achene weight (g); AY: Achene yield ( $t$ ha $\left.{ }^{-1}\right)$; BY: Biological yield ( $t$ ha $\left.a^{-1}\right)$; HI: Harvest index (\%); AOC: Achene oil contents (\%) and APC: Achene protein contents (\%).

In both sunflower hybrids, maximum number of achenes per head were counted from seed priming with $1 \mathrm{mM} B$ which was closely followed by that of with $0.1 \mathrm{mM} \mathrm{B}$ (Table 1). The achenes that were taken as control and were not subjected to any seed treatment statistically produced minimum number of achenes per head in both tested sunflower hybrids. Statistically maximum 1000 -achene weight was recorded from achenes exposed to hydropriming which was statistically at par with seed priming with 0.01 $\mathrm{mM}$ B solution (Table 1). Instead of, minimum 1000-achene weight was observed from achenes taken as control and were not exposed to any seed treatment and which were statistically similar to achenes that were subjected to seed priming with $\mathrm{B}$ at 1 and $0.1 \mathrm{mM}$ concentration. The study also indicated that 1000-achene weight was statistically higher in Hysun-33 as compared to FH-331(Table 1).

All the seed treatments significantly increased achene yield and biological yield compared with control. Statistically maximum achene yield was recorded from achenes exposed to seed priming with $1 \mathrm{mM} \mathrm{B}$ which was closely followed by that of with $0.1 \mathrm{mM}$ B. Instead of, minimum achene yield was recorded from achenes taken as control and were not exposed to any seed treatment. The study also indicated that achene yield was statistically higher in sunflower hybrid Hysun-33 as compared to FH-331(Table 1). Statistically maximum biological yield was observed from achenes exposed to seed priming with $1 \mathrm{mM} \mathrm{B}$ which was statistically similar to that of with $0.1 \mathrm{mM}$ B. Instead of, minimum biological yield was observed in achenes taken as control and were not exposed to any seed treatment. The study also indicated that biological yield was statistically higher in sunflower hybrid $\mathrm{Hy}-$ sun-33 as compared to FH-331.

The study showed that seed priming with B significantly affected harvest index of sunflower hybrids. 
Likewise, both the tested sunflower hybrids were also statistically different from each other in this regard (Table 1). All the seed treatments resulted in significantly higher value of harvest index compared with control. Statistically highest value of harvest index was calculated from achenes exposed to seed priming with $1 \mathrm{mM}$ B which was closely followed by that of with $0.1 \mathrm{mM}$ B (Table 1 ).

The study also revealed seed priming with B significantly affected the achene oil and protein contents of sunflower hybrids. Likewise, both the tested sunflower hybrids were also statistically different from each other in this regard (Table 1). Statistically higher oil contents were obtained from achenes exposed to seed priming with $1 \mathrm{mM} B$ which were statistically similar to that of with $0.1 \mathrm{mM}$ B. Statistically higher protein contents were obtained from achenes subjected to hydro-priming and were statistically similar to achenes exposed to seed priming with $0.01 \mathrm{mM} \mathrm{B}$. The study also indicated that achene protein contents were statistically higher in Hysun-33 as compared to FH-331 (Table 1).

The study revealed that seed priming with B has significant potential to improve achene yield and oil contents of sunflower hybrids. Seed priming treatments significantly affected the yield contributing parameters compared with the treatment taken as control and thus resulted in higher yield of hybrid sunflower. Untreated seeds did not perform well as compared to primed seeds due to the fact that these could not start early emergence and seedling stand establishment. Head diameter was increased in response to seed priming with B specifically at $1 \mathrm{mM}$ concentration. It may be due to improved translocation of photo assimilates from vegetative to reproductive parts under B seed priming as B is involved in translocation of sugars, which are reported having incremental effect on metabolic activities (Reddy et al., 2003). Seed priming with B resulted in increased head diameter, which resulted in higher number of achenes per head as is evident from the positive correlation between head diameter and number of achenes per head (Tahir et al., 2014). Improved head diameter and number of achenes per head may also be due to the involvement of $\mathrm{B}$ in assimilate partitioning as $\mathrm{B}$ is involved in translocation of assimilates from biomass to plant head in sunflower (Zahoor et al., 2011). 1000 -achene weight was reduced in response to B seed priming compared with control and hydroprim- ing. This was due to the negative correlation between number of achenes per head and 1000-achene weight as reported by Tahir et al. (2014). Improved biological yield as a result of seed priming with $B$ might be due to earlier and uniform emergence, which ended in increased biological yield. Improved biological yield of sunflower by the application of B has been reported by Tahir et al. (2014).

Seed priming with B significantly improved achene yield of hybrid sunflower. Improved achene yield of sunflower was due to the improved yield contributing parameters i.e. head diameter and number of achenes per head. Improved achene yield of sunflower by seed priming with $\mathrm{B}$ might be the result of enhanced dry matter partitioning towards the achenes (Zahoor et al., 2011). It may also be due to improved translocation of photo assimilates from vegetative to reproductive parts under B seed priming as B is involved in translocation of sugars, which are reported having incremental effect on metabolic activities (Reddy et al., 2003). Improved achene yield of sunflower by the application of $\mathrm{B}$ has been reported by Tahir et al. (2014). Improved harvest index by seed priming with $\mathrm{B}$ might be result of enhanced dry matter partitioning towards the achenes that resulted in improved achene yield.

The study indicated that seed priming with $\mathrm{B}$ significantly increased achene oil contents of sunflower hybrids. Improved achene oil contents of sunflower hybrids by $\mathrm{B}$ seed priming might be due to enhanced uptake of $\mathrm{B}$ in the achenes as B has significant effect on achene oil contents of sunflower (Renukadevi and Savithri, 2003). The study also indicated that seed priming with B significantly decreased achene protein contents of sunflower hybrids which may be due to the involvement of $\mathrm{B}$ with the mechanism of protein synthesis (Tanaka and Fujiwara, 2008). It may also be due to the negative correlation between achene oil and protein contents under B nutrition (Tahir et al., 2013).

\section{Conclusions and Recommendations}

The study concluded that all the seed treatments significantly improved achene yield, yield attributes and oil contents of sunflower. However, seed priming with $1 \mathrm{mM} B$ solution was found to be the best. Thus seed priming with $1 \mathrm{mM}$ B solution may be helpful in improving achene yield and oil contents of hybrid sunflower. 
Author's Contribution

Muhammad Kashif Asghar conducted experiment and collected data, Muhammad Aqeel Sarwar and Shahid Riaz Malik provided technical input. Waqas Ahmad did statistical analysis, while Sumaira Zareen, Safdar Ali and Abid Ali wrote the article.

\section{References}

Abid, M., N. Ahmad, A. Asghar, M.A. Chaudhry and J. Hussain. 2007. Influence of soil-applied $B$ on yield, fiber quality and leaf $B$ contents of cotton (Gossypium hirsutum L.). J. Agric. Soc. Sci. 3: 7-10.

Ahmad, R.T., T.A. Malik, I.A. Khan and M.J.A. Jaskani. 2009. Genetic analysis of some morpho-physiological traits related to drought stress in cotton (Gossypium hirsutumL.). Int. J. Agric. Biol. 11: 235-240.

Alam, M.S., K.J. Ali and A. Hoque. 2017. Yield and yield component of chickpea as affected by boron application. J. Exp. Agric. Int. 15: 1-9. https://doi.org/10.9734/JEAI/2017/8944

Alloway, B.J. 2008. Micronutrient deficiencies in global crop production. Springer Science, Business media B.V. Netherlands.

Farooq, M., S.M.A. Basra, M. Khalid, R. Tabassum and T. Mehmood. 2006. Nutrient homeostasis, reserves metabolism and seedling vigor as affected by seed priming in coarse rice. Can. J. Bot. 84: 1196-1202. https://doi.org/10.1139/ b06-088

GoP. 2014. Economic Survey of Pakistan, 201314. Ministry of Food, Agriculture and Livestock. Finance Division, Economic Advisors Wing, Islamabad, Pakistan. pp. 29-30.

Imtiaz, M., A. Rashid, P. Khan, M.Y. Memon and M. Aslam. 2010. The role of micronutrients in crop production and human health. Pak. J. Bot. 42: 2565-2578.

Mengel, K., E.A. Kirkby, H. Kosegarten and T. Appel. 2001. Principles of plant nutrition. Kluwer acad. publishers, Dordrecht, Netherlands. https://doi.org/10.1007/978-94-010-1009-2

Rashid, A. and J. Ryan. 2004. Micronutrient constraints to crop production in soils with Med- iterranean-type characteristics: Rev. J. Plant Nutr. 27: 959-975. https://doi.org/10.1081/ PLN-120037530

Reddy, N.Y.A., R.U. Shaanker, T.G. Prasad and M.U. Kumar. 2003. Physiological approaches to improving harvest index and productivity in sunflower. Helia. 26: 81-90. https://doi. org/10.2298/HEL0338081R

Rehman, A., M. Farooq, Z.A. Cheema and A.Wahid. 2012. Seed priming with boron improves growth and yield of fine grain aromatic rice. Plant Gro. Regu. 68: 189-201

Renukadevi, A. and P. Savithri. 2003. Sunflower (Helianthus annuus L.) oil yield and quality as influenced by B application. Madras Agric. J. 91: 74-76.

Saleem, R., M.U. Farooq and R. Ahmad. 2003. Bio-economic assessment of different sunflower based intercropping system at different geometric configurations. Pak. J. Biol. Sci. 6: 1187-1190. https://doi.org/10.3923/ pjbs.2003.1187.1190

Sarwar, M.A. 2015. Evaluating role of plant growth promoting rhizobacteria for improving nitrogen and phosphorus use efficiency in sunflower. 2015. Ph.D. thesis, Univ. Agric. Faisalabad, Pak. Steel, R.G.D., J.H. Torrie and D.A. Dicky. 1997. Principles and procedures of statistics: A biometrical approach, $3^{\text {rd }}$ ed. pp. 172-177. McGraw Hill Book Int. Co., New York.

Tahir, M., M.Y. Ishaq, A.A. Sheikh, M. Naeem and A. Rehman. 2014. Effect of B on yield and quality of sunflower under agro-ecological conditions of Faisalabad Pakistan. Sci. Agric. 7: 19-24.

Tahir, M., S. Ashraf and M. Ibrahim. 2013. Effect of foliar application of B on yield and quality of sunflower (Helianthus annuus L.). Crop Environ. 4: 23-27.

Tanaka, M. and T. Fujiwara. 2008. Physiological roles and transport mechanisms of $\mathrm{B}$ : perspectives from plants. Eur. J. Physiol. 456: 671-677. https://doi.org/10.1007/s00424-007-0370-8

Zahoor, R., S.M.A. Basra, H. Munir, M.A. Nadeem and S. Yousaf. 2011. Role of B in improving assimilate partitioning and achene yield in sunflower. J. Agric. Soc. Sci. 7: 49-55. 